\title{
Effects of three different bleaching agents on microhardness and roughness of composite sample surfaces finished with different polishing techniques
}

\author{
İhsan Yikilgan ${ }^{1}$, Hanife Kamak ${ }^{2}$, Sinem Akgul ${ }^{2}$, Suat Ozcan ${ }^{1}$, Oya Bala ${ }^{3}$
}

\footnotetext{
${ }^{1}$ Assist. Prof. Dr., DDS, PhD. Gazi University Faculty of Dentistry, Department of Restorative Dentistry, Ankara, Turkey

${ }^{2}$ Research Assistant. Gazi University Faculty of Dentistry, Department of Restorative Dentistry, Ankara, Turkey

${ }^{3}$ Prof. Dr., DDS, PhD. Gazi University Faculty of Dentistry, Department of Restorative Dentistry, Ankara, Turkey
}

Correspondence:

Gazi University Faculty of Dentistry

Department of Restorative Dentistry

06510 Emek, Ankara, Turkey

hanife.kamak@hotmail.com

Received: 29/03/2016 Accepted: 20/07/2016

\begin{abstract}
Yikilgan İ, Kamak H, Akgul S, Ozcan S, Bala O. Effects of three different bleaching agents on microhardness and roughness of composite sample surfaces finished with different polishing techniques. J Clin Exp Dent. 2017;9(3):e460-5.

http://www.medicinaoral.com/odo/volumenes/v9i3/jcedv9i3p460.pdf
\end{abstract}

\begin{tabular}{l}
\hline Article Number: $53136 \quad$ http://www.medicinaoral.com/odo/indice.htm \\
C Medicina Oral S. L. C.I.F. B 96689336 - eISSN: 1989-5488 \\
eMail: jced@jced.es \\
Indexed in: \\
$\quad$ Pubmed \\
Pubmed Central $@$ (PMC) \\
Scopus \\
DOI® System
\end{tabular}

\begin{abstract}
Background: The aim of this study was to evaluate effects of different polishing methods and whitening agents on surface hardness and roughness of nano-hybrid composite resin.

Material and Methods: In total, one hundred twenty disc-shaped specimens were prepared to nano-hybrid composite (Charisma Diamond). 60 samples were used for microhardness measurements and the others were used for the evaluation of surface roughness. Samples were divided randomly into two subgroups ( $\mathrm{n}=30$ each). In first group a low-viscosity liquid polishing agent (Biscover LV) was applied. In the second group, nothing was applied. All the samples were stored in distilled water at $37^{\circ} \mathrm{C}$ for $24 \mathrm{~h}$. After initial measurements were completed, samples were divided randomly into three subgroups for bleaching application. 10\% carbamide peroxide (Opalescence PF), 45\% carbamide peroxide (Opalescence PF Quick), 38\% hydrogen peroxide (Opalescence Boost) was applied. Then microhardness and surface roughness measurements of samples were repeated and data were recorded as final values for each sample.

Results: When the polishing techniques were compared, no signicant difference was observed in surface hardness and roughness. When the bleaching agents were compared, the $10 \%$ carbamide peroxide and $38 \%$ hydrogen peroxide containing bleaching agent groups showed statistically significant differences between pre- and post-procedure hardness values $(p<0.05)$.

Conclusions: Office-type bleaching agent containing $\mathrm{CP}$ was observed to be more secure for composite resins than other bleaching agents. No negative effect of glaze materials on the protection of surface roughness and hardness of composite resin was observed.
\end{abstract}

Key words: Composite resin, bleaching, surface hardness, surface roughness. 


\section{Introduction}

Today, with an increase in esthetic expectations, esthetic applications have also gained in popularity. Bleaching is one non-invasive application that can protect natural dentition and meet esthetic expectations. Bleaching agents bleach the tooth by creating an oxidative reaction. There may be various negative effects of oxidative reactions on tooth tissues and restorative dental materials. Haywood et al. (1) reported that different concentrations of bleaching agents resulted in decreases in enamel microhardness. Also, these agents may cause increases in surface roughness and decreases in the surface hardness of restorative materials (2-6).

Surface roughness and hardness are important markers for the clinical success of restorations. Plaque accumulation, discoloration, gingival irritation, and secondary caries may be observed on rough restoration surfaces. Additionally, materials that have reduced surface hardness are more susceptible to deformation. Surface roughness and hardness of composite restorations are affected by structural properties of the material, such as monomer type, filler type, and percentage. Also, finishing and polishing restorations influence roughness and the hardness of composite materials. Finishing and polishing instruments and surface sealants are used to smooth restoration surfaces. Surface sealants are resin-based materials with high organic content, applied to restoration surfaces, to cover micro-pitting on restorations. The use of these materials, also discussed at the beginning of the 1990s, has been controversial (7). Although some researchers concluded that surface sealants had positive effects on the physical properties of restorations, others disagreed (8-13).

Many studies have evaluated the effects of bleaching processes on the surface roughness and hardness of composite resins. However, no reported research has evaluated the effects of bleaching processes on the surface characteristics of composite resins polished with a surface sealant.

The main aim of this study was to evaluate the changes in surface roughness and hardness of composite resin po- lished with a surface sealant. For this purpose, bleaching agents with three different compositions and concentrations were used (Opalescence PF, Opalescence PF Quick, and Opalescence Boost). Thus, we sought to determine the relationship between surface roughness and hardness of resin composites and the type of bleaching agent.

\section{Material and Methods}

\section{-Preparation of Samples}

Materials used in this study and chemical components are shown in table 1. Composite resin (Charisma Diamond, Heraeus Kulzer, Germany) samples were prepared using 5-mm diameter and 2-mm deep Teflon molds. After composite resin was placed in the molds, a Mylar strip (Henry Schein, Melville, NY, USA) was placed, and a glass slab was laid on the mold. Then, the composite material was polymerized with a LED light curing unit (G Light, GC, USA) for $20 \mathrm{~s}$ according to the manufacturer's protocol. Composite samples were polished with aluminum oxide-coated polishing discs (Sof-Lex, 3M ESPE, USA) 10 times for each disc on the surface of the samples. In total, 120 samples were prepared. Of them, 60 samples were used for microhardness measurements and the remaining samples were used for the evaluation of surface roughness.

Samples were divided randomly into two subgroups ( $\mathrm{n}=30$ each). A low-viscosity liquid polishing agent, Biscover LV (Bisco, Schaumburg, IL, USA), was used with the first group of samples in accordance with the manufacturer's instructions. First, 37\% orthophosphoric acid was applied to the sample surface for $15 \mathrm{~s}$, and then rinsed and dried with an air-water spray. A thin coat of Biscover LV was applied by brush on the sample surfaces, dried with mild air, and polymerized with a LED light curing unit for $30 \mathrm{~s}$ after waiting for $15 \mathrm{~s}$ for evaporation without air application. In the second group, nothing was applied to the surfaces as a control. All the samples were stored in distilled water at $37^{\circ} \mathrm{C}$ for $24 \mathrm{~h}$. -Microhardness measurements Initial microhardness measurements were made with a Vickers hardness testing machine (Shimadzu HMV-2,

Table 1. Materials used in this study.

\begin{tabular}{|c|c|c|}
\hline Material Name & Type & Contents \\
\hline Charisma Diamond & Nano hybrid composite & TCD-DI-HEA, UDMA, barium aluminum fluoride glass \\
\hline Opalescence ${ }^{\circledR} \mathrm{PF}$ & $\begin{array}{l}\text { Home type bleaching } \\
\text { agent }\end{array}$ & $\begin{array}{l}10 \% \text { carbamide peroxide, potassium nitrate, } 0.11 \% \text { fluoride, carbopol, } \\
\text { glycerin }\end{array}$ \\
\hline $\begin{array}{l}\text { Opalescence }{ }^{\circledR} \quad \text { PF } \\
\text { Quick }\end{array}$ & $\begin{array}{l}\text { Office type bleaching } \\
\text { agent }\end{array}$ & $\begin{array}{l}45 \% \text { carbamide peroxide, potassium nitrate, } 0.11 \% \text { fluoride, carbopol, } \\
\text { glycerin }\end{array}$ \\
\hline Opalescence $\AA$ Boost & $\begin{array}{l}\text { Office type bleaching } \\
\text { agent }\end{array}$ & $\begin{array}{c}\text { Gel: } 38 \% \text { hydrogen peroxide. } \\
\text { Activator: Potassium hydroxide, } 1.1 \% \text { to } 3 \% \text { fluoride and potassium } \\
\text { nitrate }\end{array}$ \\
\hline
\end{tabular}


Japan). Measurements were performed on samples with a 100-g load applied by the indenter for $30 \mathrm{~s}$ and this measurement was repeated in three different regions of each sample. The mean microhardness was calculated using the values of the three indentations and recorded as the Vickers hardness value of the sample.

After initial microhardness measurements were completed, composite samples in each group were divided randomly into three subgroups for bleaching application. Bleaching agent containing 10\% carbamide peroxide (Opalescence PF; Ultradent Products Inc., South Jordan, UT, USA) was applied $8 \mathrm{~h}$ per day for 14 days, in accordance with the manufacturer's instructions. Bleaching agent containing $45 \%$ carbamide peroxide (Opalescence PF Quick; Ultradent Products Inc.) was applied according to manufacturer's instructions on surfaces of samples in Group 2 for 30 min and this application was repeated for three times. Bleaching agent containing 38\% hydrogen peroxide (Opalescence Boost; Ultradent Products Inc.) was applied according to the manufacturer's instructions on the sample surface in Group 3 for 20 min, twice, over 2 days. After the application of the bleaching agents, microhardness measurements of samples were repeated and data were recorded as final microhardness values for each sample.

\section{-Surface roughness measurements}

Initial surface roughness measurements of the samples were conducted using a profilometer roughness measuring device (SJ-301 Mitutuya Surfest, Japan). The end of the profilometer device was in contact with the centre of the sample, as far as possible, during the measurement, and it was performed from a distance of $0.8 \mathrm{~mm}$, and repeated for three different regions for each sample. The mean of the three measurements was recorded as the surface roughness value of the sample. After the initial surface roughness measurement, composite samples in each group were divided randomly into three subgroups for bleaching application, as was done for the surface hardness samples. After application of the bleaching agent, surface roughness measurements of samples were repeated and data were recorded as the final surface roughness value for each sample.

-Statistical Analysis

Statistical analyses were performed using the SPSS software (ver. 15.0 for Windows). The normal distribution of the continuous quantitative variables was evaluated with the Kolmogorov-Smirnov test and the homogeneity of variance was evaluated with Levene's test. As the data were normally distributed, descriptive statistics were used.

The significance of differences in mean values between groups was evaluated by one-way ANOVA. Bonferroni corrections were used with a post hoc test to control type 1 error in multiple comparisons. The importance of mean value differences within groups before and af- ter the procedures was investigated with paired t-tests. $P$ values $<0.05$ were considered to indicate statistical significance.

\section{Results}

Descriptive statistics of surface hardness results are shown in table 2 . When the polishing techniques were compared, no significant effect was found between the groups in terms of protecting surface hardness $(p>$ $0.05)$.

When the bleaching agents were compared, the $10 \%$ carbamide peroxide- and 38\% hydrogen peroxidecontaining bleaching agent groups showed statistically significant differences between pre- and post-procedure hardness values upon surface sealant application $(p<$ 0.05; Table 3).

Descriptive statistics of the surface roughness measurements shown in table 4 . When different polishing techniques were compared, it was found that applying Biscover $\mathrm{LV}$, or not, had no significant effect on surface roughness $(p>0.05)$. As a result of evaluating the bleaching agents, no statistically significant difference was found between the surface roughness measurements before and after bleaching in any group $(p>0.05$; Table 5).

\section{Discussion}

Surface sealants are one of the alternatives that can be used for ensuring a smooth surface on composite restorations. Many studies have examined the effects of composite surface sealants on the properties of composite resin surfaces. However, there has been no previously reported study that evaluated how surface properties of composite resins are affected by bleaching agents after surface sealant application. Thus, our study is unique from this perspective.

Some researchers have reported effects of different aging applications on surface sealants using composite resins. Catelan et al. (11) applied artificial aging to composite resins under UV light, Briso et al. (14) applied aging to composite resins with different acidic solutions, and Karaaslan et al. (10) applied aging to composite resins with thermal cycling. In their results, surface roughness of the surface sealant samples used in all these studies was not affected adversely by the aging processes. In our study too, no significant difference was seen between the glazed and non-glazed samples in surface roughness changes. Thus, our results were consistent with these previous studies.

Many studies have evaluated the effects of bleaching agents on the surface roughness of composite resins. Some studies have reported that bleaching agents have no significant effects on the surface roughness of composite resins, while others have reported that bleaching agents increased the surface roughness (15-17). In our study, none of the bleaching agents tested showed any 
Table 2. Descriptive statistics data of surface hardness results of the samples (mean, standard deviation, standard error mean, minimum and maximum values).

\begin{tabular}{|c|c|c|c|c|c|c|c|c|}
\hline $\begin{array}{c}\text { Surface } \\
\text { finish }\end{array}$ & Whitening Agent & & $\mathbf{N}$ & Mean & $\begin{array}{c}\text { Std. } \\
\text { Deviation }\end{array}$ & $\begin{array}{c}\text { Std. Error } \\
\text { Mean }\end{array}$ & Minimum & Maximum \\
\hline \multirow[t]{6}{*}{ Biscover } & \multirow{2}{*}{$\begin{array}{c}\text { Group 1 } \\
\text { (Opalescence }{ }^{\circledR} \text { PF) }\end{array}$} & first measurement & 10 & 66,40 & 4,78 & 1,51 & 58,3 & 72,7 \\
\hline & & last measurements & 10 & 62,70 & 2,43 & 0,77 & 58,4 & 67,4 \\
\hline & \multirow{2}{*}{$\begin{array}{c}\text { Group 2 } \\
\text { (Opalescence®PF Quick) }\end{array}$} & first measurement & 10 & 55,52 & 7,81 & 2,47 & 47,1 & 70,6 \\
\hline & & last measurements & 10 & 51,60 & 5,07 & 1,60 & 44,7 & 60,4 \\
\hline & \multirow{2}{*}{$\begin{array}{c}\text { Group 3 } \\
\text { (Opalescence }{ }^{\circledR} \text { Boost) }\end{array}$} & first measurement & 10 & 61,24 & 2,99 & 0,95 & 54,8 & 64,8 \\
\hline & & last measurements & 10 & 53,67 & 3,78 & 1,19 & 49,8 & 60,2 \\
\hline \multirow[t]{6}{*}{ Sof-Lex } & \multirow{2}{*}{$\begin{array}{c}\text { Group 1 } \\
\text { (Opalescence }{ }^{\circledR} \text { PF) }\end{array}$} & first measurement & 10 & 92,25 & 4,26 & 1,35 & 86,1 & 99,3 \\
\hline & & last measurements & 10 & 86,08 & 5,52 & 1,74 & 76,4 & 96,4 \\
\hline & \multirow{2}{*}{$\begin{array}{c}\text { Group 2 } \\
\text { (Opalescence®PF Quick) }\end{array}$} & first measurement & 10 & 95,54 & 7,18 & 2,27 & 84,5 & 109,0 \\
\hline & & last measurements & 10 & 93,95 & 3,56 & 1,13 & 88,4 & 99,0 \\
\hline & \multirow{2}{*}{$\begin{array}{c}\text { Group 3 } \\
\text { (Opalescence }{ }^{\circledR} \text { Boost) }\end{array}$} & first measurement & 10 & 90,37 & 7,45 & 2,36 & 79,8 & 101,0 \\
\hline & & last measurements & 10 & 83,79 & 2,94 & 0,93 & 80,2 & 87,8 \\
\hline
\end{tabular}

Table 3. Statistical evaluation of the relationship between the amount of changes in surface hardness before and after the application of bleaching agent for all experimental groups.

\begin{tabular}{|c|c|c|c|c|c|c|c|c|c|c|c|}
\hline \multirow{3}{*}{$\begin{array}{l}\text { Surface } \\
\text { finish }\end{array}$} & \multirow{3}{*}{ Whitening Agent } & & \multicolumn{5}{|c|}{ Paired Differences } & \multirow{3}{*}{$\mathrm{t}$} & \multirow{3}{*}{ df } & \multirow{3}{*}{$\begin{array}{c}\text { Sig. } \\
\text { difference } \\
\text { before and } \\
\text { after } \\
\text { treatment }\end{array}$} & \multirow{3}{*}{$\begin{array}{c}\text { The } \\
\text { between- } \\
\text { group } \\
\text { difference } \\
\text { sig. }\end{array}$} \\
\hline & & & \multirow[t]{2}{*}{ Mean } & \multirow[t]{2}{*}{$\begin{array}{c}\text { Std. } \\
\text { Deviation }\end{array}$} & \multirow[t]{2}{*}{$\begin{array}{l}\text { Std. } \\
\text { Error } \\
\text { Mean }\end{array}$} & \multicolumn{2}{|c|}{$\begin{array}{c}\mathbf{9 5 \%} \text { Confidence } \\
\text { Interval of the } \\
\text { Difference }\end{array}$} & & & & \\
\hline & & & & & & Upper & Lower & & & & \\
\hline \multirow[t]{3}{*}{ Biscover } & $\begin{array}{c}\text { Group 1 } \\
\text { (Opalescence }{ }^{\circledR} \text { PF) }\end{array}$ & $\begin{array}{l}\text { the last - the } \\
\text { first } \\
\text { measurement }\end{array}$ & 3,70 & 4,20 & 1,33 & _ 0,69 & 6,70 & 2,781 & 9 & $0,021^{*}$ & \multirow{3}{*}{0,136} \\
\hline & $\begin{array}{c}\text { Group 2 } \\
\text { (Opalescence }{ }^{\circledR} \text { PF } \\
\text { Quick) }\end{array}$ & $\begin{array}{l}\text { the last - the } \\
\text { first } \\
\text { measurement }\end{array}$ & 3,92 & 6,19 & 1,96 & 0,51 & _8,35 & 2,003 & 9 & 0,076 & \\
\hline & $\begin{array}{c}\text { Group 3 } \\
\text { (Opalescence }{ }^{\circledR} \\
\text { Boost) }\end{array}$ & $\begin{array}{l}\text { the last - the } \\
\text { first } \\
\text { measurement }\end{array}$ & $-7,57$ & 3,15 & 1,00 & 5,32 & ${ }_{-9,82}$ & 7,595 & 9 & $0,000^{*}$ & \\
\hline \multirow[t]{3}{*}{ Sof-Lex } & $\begin{array}{c}\text { Group 1 } \\
\text { (Opalescence }{ }^{\circledR} \text { PF) }\end{array}$ & $\begin{array}{l}\text { the last - the } \\
\text { first } \\
\text { measurement }\end{array}$ & 6,17 & 7,95 & 2,51 & 0,48 & $-11,86$ & 2,454 & 9 & $0,037^{*}$ & \multirow[t]{3}{*}{0,269} \\
\hline & $\begin{array}{c}\text { Group 2 } \\
\text { (Opalescence } ® \text { PF } \\
\text { Quick) }\end{array}$ & $\begin{array}{l}\text { the last - the } \\
\text { first } \\
\text { measurement }\end{array}$ & _ 1,59 & 6,15 & 1,95 & 2,81 & 5,99 & 0,817 & 9 & 0,435 & \\
\hline & $\begin{array}{c}\text { Group 3 } \\
\text { (Opalescence } \mathbb{} \\
\text { Boost) }\end{array}$ & $\begin{array}{l}\text { the last - the } \\
\text { first } \\
\text { measurement }\end{array}$ & 6,58 & 8,12 & 2,57 & 0,77 & 12,39 & 2,561 & 9 & $0,031^{*}$ & \\
\hline
\end{tabular}

significant effect on the surface roughness of the composite resin. The roughness values of some samples in the experimental groups in our study were more than 0.2 $\mu \mathrm{m}$. Generally, $0.2 \mu \mathrm{m}$, the average surface roughness of the experimental groups, is considered a clinically acceptable value.

Differing results have been reported in studies that have examined the effects of bleaching agents on the surface hardness of composite resins. Some studies have reported that the bleaching agents have no significant effect on the roughness of composite resins (18-20), while others have reported that they reduce the hardness of the surface (21-23). In our study, while office-type bleaching agent containing 38\% HP and home bleaching agent containing $10 \% \mathrm{CP}$ caused significant reductions in surface hardness of the composite resin, an office- type bleaching agent containing $45 \% \mathrm{CP}$ did not cause any significant effect on the surface hardness of the composite.

Differences in office-type whitening agents may have resulted from the difference between the concentrations of agents. When $\mathrm{CP}$ is in contact with water, $\mathrm{H}_{2} \mathrm{O}_{2}$ emerges, in as much as a $30-40 \%$ concentration (24). That we used $45 \% \mathrm{CP}$ gel that generates $\mathrm{H}_{2} \mathrm{O}_{2}$ to about half of that level in the gel containing HP in our study may have been why there was no significant change in surface hardness in the $\mathrm{CP}$ groups.

Differences between application periods may have affected the difference between home bleaching gel containing $\mathrm{CP}$ and office-type gel containing $\mathrm{CP}$. While home bleaching gel was applied for $8 \mathrm{~h}$ every day for 14 days, office-type gel was applied three times for $30 \mathrm{~min}$, 
Table 4. Descriptive statistical data of surface roughness of sample (mean, standard deviation, standard error mean, minimum and maximum value).

\begin{tabular}{|c|c|c|c|c|c|c|c|c|}
\hline $\begin{array}{c}\text { Surface } \\
\text { finish }\end{array}$ & Whitening Agent & & $\mathbf{N}$ & Mean & $\begin{array}{c}\text { Std. } \\
\text { Deviation }\end{array}$ & $\begin{array}{l}\text { Std. Error } \\
\text { Mean }\end{array}$ & Minimum & Maximum \\
\hline \multirow[t]{6}{*}{ Biscover } & \multirow{2}{*}{$\begin{array}{c}\text { Group 1 } \\
\left(\text { Opalescence }{ }^{\circledR} \mathrm{PF}\right)\end{array}$} & first measurement & 10 & 0,16 & 0,07 & 0,02 & 0,08 & 0,29 \\
\hline & & last measurements & 10 & 0,17 & 0,08 & 0,03 & 0,08 & 0,36 \\
\hline & \multirow{2}{*}{ 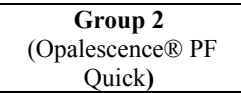 } & first measurement & 10 & 0,15 & 0,08 & 0,03 & 0,08 & 0,29 \\
\hline & & last measurements & 10 & 0,14 & 0,04 & 0,01 & 0,09 & 0,20 \\
\hline & \multirow{2}{*}{$\begin{array}{c}\text { Group 3 } \\
\text { (Opalescence }\left({ }^{\circledR} \text { Boost) }\right.\end{array}$} & first measurement & 10 & 0,15 & 0,06 & 0,02 & 0,09 & 0,26 \\
\hline & & last measurements & 10 & 0,16 & 0,05 & 0,01 & 0,09 & 0,23 \\
\hline \multirow[t]{6}{*}{ Sof-Lex } & \multirow{2}{*}{$\begin{array}{c}\text { Group 1 } \\
\left(\text { Opalescence }{ }^{\circledR} \mathrm{PF}\right)\end{array}$} & first measurement & 10 & 0,12 & 0,02 & 0,00 & 0,09 & 0,13 \\
\hline & & last measurements & 10 & 0,12 & 0,02 & 0,01 & 0,09 & 0,16 \\
\hline & \multirow{2}{*}{$\begin{array}{c}\text { Group 2 } \\
\text { (Opalescence }{ }^{\circledR} \text { PF } \\
\text { Quick) }\end{array}$} & first measurement & 10 & 0,14 & 0,03 & 0,01 & 0,10 & 0,20 \\
\hline & & last measurements & 10 & 0,14 & 0,02 & 0,01 & 0,10 & 0,17 \\
\hline & \multirow{2}{*}{$\begin{array}{c}\text { Group 3 } \\
\text { (Opalescence }{ }^{\circledR} \text { Boost) }\end{array}$} & first measurement & 10 & 0,14 & 0,02 & 0,01 & 0,10 & 0,18 \\
\hline & & last measurements & 10 & 0,17 & 0,04 & 0,01 & 0,10 & 0,24 \\
\hline
\end{tabular}

Table 5. Statistical evaluation of the relationship between the amount of changes in surface roughness before and after the application of bleaching agent for all experimental groups.

\begin{tabular}{|c|c|c|c|c|c|c|c|c|c|c|c|}
\hline \multirow{3}{*}{$\begin{array}{l}\text { Surface } \\
\text { finish }\end{array}$} & \multirow{3}{*}{ Whitening Agent } & & \multicolumn{5}{|c|}{ Paired Differences } & \multirow{3}{*}{$\mathbf{t}$} & \multirow{3}{*}{ df } & \multirow{3}{*}{$\begin{array}{c}\text { Sig. } \\
\text { difference } \\
\text { before and } \\
\text { after } \\
\text { treatment }\end{array}$} & \multirow{3}{*}{$\begin{array}{c}\text { The } \\
\text { between } \\
\text { group } \\
\text { difference } \\
\text { sig }\end{array}$} \\
\hline & & & \multirow[t]{2}{*}{ Mean } & \multirow[t]{2}{*}{$\begin{array}{c}\text { Std. } \\
\text { Deviation }\end{array}$} & \multirow[t]{2}{*}{$\begin{array}{l}\text { Std. } \\
\text { Error } \\
\text { Mean }\end{array}$} & \multicolumn{2}{|c|}{$\begin{array}{l}\text { 95\% Confidence } \\
\text { Interval of the } \\
\text { Difference }\end{array}$} & & & & \\
\hline & & & & & & Upper & Lower & & & & \\
\hline \multirow[t]{3}{*}{ Biscover } & $\begin{array}{c}\text { Group 1 } \\
\left(\text { Opalescence }{ }^{\circledR} \mathrm{PF}\right)\end{array}$ & $\begin{array}{c}\text { the last - the first } \\
\text { measurement }\end{array}$ & 0,01 & 0,05 & 0,02 & 0,05 & ${ }_{-} 0,02$ & $-1,062$ & 9 & 0,316 & \multirow[t]{3}{*}{0,715} \\
\hline & $\begin{array}{c}\text { Group 2 } \\
\text { (Opalescence }{ }^{\circledR} \text { PF } \\
\text { Quick) }\end{array}$ & $\begin{array}{l}\text { the last - the first } \\
\text { measurement }\end{array}$ & 0,01 & 0,09 & 0,03 & 0,06 & 0,07 & 0,247 & 9 & 0,810 & \\
\hline & $\begin{array}{c}\text { Group 3 } \\
\left(\text { Opalescence }{ }^{\circledR} \text { Boost }\right)\end{array}$ & $\begin{array}{c}\text { the last - the first } \\
\text { measurement }\end{array}$ & 0,01 & 0,04 & 0,01 & 0,04 & - 0,03 & $-0,473$ & 9 & 0,647 & \\
\hline \multirow[t]{3}{*}{ Sof-Lex } & $\begin{array}{c}\text { Grup 1 } \\
(\text { Opalescence }(\mathrm{PF})\end{array}$ & $\begin{array}{c}\text { the last - the first } \\
\text { measurement }\end{array}$ & 0,00 & 0,02 & 0,01 & 0,02 & 0,01 & $-1,210$ & 9 & 0,257 & \multirow[t]{3}{*}{0,368} \\
\hline & $\begin{array}{l}\text { Group 2 } \\
\text { (Opalescence }{ }^{\circledR} \\
\text { Quick) }\end{array}$ & $\begin{array}{l}\text { the last - the first } \\
\text { measurement }\end{array}$ & 0,00 & 0,02 & 0,01 & 0,01 & 0,02 & 0,547 & 9 & 0,598 & \\
\hline & $\begin{array}{c}\text { Group 3 } \\
\text { (Opalescence } \AA \text { Boost) }\end{array}$ & $\begin{array}{l}\text { the last - the first } \\
\text { measurement }\end{array}$ & 0,02 & 0,03410 & 0,01 & $-0,04$ & 0,03 & $-1,947$ & 9 & 0,083 & \\
\hline
\end{tabular}

according to the instructions. Although the office-type gel had a lower concentration, the long implementation period may have been more effective in damaging the surface of the composite resin. Malkondu et al. (23) evaluated the effects of two different home bleaching gels on surface hardness of different ceramic and composite resins. While the agent used for short-term application caused hardness changes in only one composite group, the long-term application agent caused deterioration of hardness in all the ceramic and composite groups. Lima et al. (22) evaluated the effects of home bleaching gel containing CP and office-type gel containing HP on the surface hardness of composite resins. They reported that the home bleaching agent caused a significant reduction in surface hardness of the composite resin compared with the control group. The results of these studies are consistent with our results.
Studies have reported that the use of glaze material reduces the surface hardness of composite resins but have also reported an increase in resistance to degradation in composite resins $(11,14)$. In our study, it was seen that the initial surface hardness of groups where glaze material was used was significantly lower than the groups where glaze material was not used. However, it was found that bleaching applications had no significant effect on hardness. Thus, our work is consistent with these previous studies.

\section{Conclusions}

1) Office-type bleaching agent containing $\mathrm{CP}$ was observed to be more secure for composite resins than an office-type bleaching agent containing HP.

2) Despite the low concentrations, home bleaching agents can lead to a significant decrease in the surface 
hardness of composite resins because of their long application period. Thus, for the bleaching process of teeth restored with composite resin, office-type bleaching agent containing $\mathrm{CP}$ that is applied for a shorter period of time may be more appropriate.

3) No effect of the bleaching agents on surface roughness of the composite resins was observed.

4) No negative effect of glaze materials on the protection of surface roughness and hardness of composite resin was observed.

\section{References}

1. Haywood VB, Heymann HO. Nightguard vital bleaching: how safe is it? Quintessence Int. 1991;22:515-23.

2. Rotstein I, Avron Y, Shemesh H, Dogan H, Mor C, Steinberg D. Factors affecting mercury release from dental amalgam exposed to carbamide peroxide bleaching agent. American journal of dentistry. 2004; $17: 347-50$

3. Haywood VB. Greening of the Tooth-Amalgam Interface during Extended 10\% Carbamide Peroxide Bleaching of Tetracycline-Stained Teeth: A Case Report. Journal of Esthetic and Restorative Dentistry. 2002;14:12-7.

4. Deliperi S. Interaction of peroxides with amalgam: a case report. Journal of Esthetic and Restorative Dentistry. 2007;19:208-211.

5. Moraes RR, Marimon JLM, Schneider LFJ, Sobrinho LC, Camacho GB, Bueno M. Carbamide peroxide bleaching agents: effects on surface roughness of enamel, composite and porcelain. Clinical Oral Investigations. 2006;10:23-8.

6. Türker SB, Biskin T. The effect of bleaching agents on the microhardness of dental aesthetic restorative materials. Journal of oral rehabilitation. 2002;29:657-61.

7. Ratanapridakul K, Leinfelder KF, Thomas J. Effect of finishing on the in vivo wear rate of a posterior composite resin. The Journal of the American Dental Association. 1989;118:333-5.

8. Sarac D, Sarac YS, Kulunk S, Ural C, Kulunk T. The effect of polishing techniques on the surface roughness and color change of composite resins. The Journal of prosthetic dentistry. 2006;96:33-40.

9. Lopes MB, Saquy PC, Moura SK, Wang L, Graciano FMO, Correr Sobrinho L, et al. Effect of different surface penetrating sealants on the roughness of a nanofiller composite resin. Brazilian dental journal. 2012;23:692-7.

10. Karaarslan ES, Bulbul M, Yildiz E, Secilmis A, Sari F, Usumez A. Effects of different polishing methods on color stability of resin composites after accelerated aging. Dental materials journal. 2013;32:5867.

11. Catelan A, Briso AL, Sundfeld RH, Dos Santos PH. Effect of artificial aging on the roughness and microhardness of sealed composites. Journal of Esthetic and Restorative Dentistry. 2010; 22:324-30.

12. Takeuchi CY, Flores VO, Dibb RP, Panzeri H, Lara EH, Dinelli W. Assessing the surface roughness of a posterior resin composite: effect of surface sealing. Operative Dentistry. 2003;28:281-6.

13. Zimmerli B, Koch T, Flury S, Lussi A. The influence of toothbrushing and coffee staining on different composite surface coatings. Clinical oral investigations. 2012;16:469-79.

14. Briso ALF, Caruzo LP, Guedes APA, Catelan A, Santos PD. In vitro evaluation of surface roughness and microhardness of restorative materials submitted to erosive challenges. Operative dentistry. 2011;36:397-402.

15. Wang L, Francisconi LF, Atta MT, dos Santos JR, Del Padre NC, Gonini A. Effect of bleaching gels on surface roughness of nanofilled composite resins. European journal of dentistry. 2011;5:173.

16. Langsten RE, Dunn WJ, Hartup GR, Murchison DF. Higher-concentration carbamide peroxide effects on surface roughness of composites. Journal of Esthetic and Restorative. 2002;14:92-6.

17. Mohammadi N, Kimyai S, Abed-Kahnamoii M, Ebrahimi-Chaharom ME, Sadr A, Daneshi M. Effect of $15 \%$ carbamide peroxide bleaching gel on color stability of giomer and microfilled composite resin: An in vitro comparison. Med Oral Patol Oral Cir Bucal. 2012; 17:e1082-8.

18. Silva Costa SX, Becker AB, de Souza Rastelli AN, Monteiro Loffredo LDC, de Andrade MF, Bagnato VS. Effect of four bleaching regimens on color changes and microhardness of dental nanofilled composite. Int J Dent. 2009;2009:313845.

19. Polydorou O, Hellwig E, Auschill TM. The effect of at-home bleaching on the microhardness of six esthetic restorative materials. The Journal of the American Dental Association. 2007;138:978-84.

20. Yu H, Li Q, Hussain M, Wang Y. Effects of bleaching gels on the surface microhardness of tooth-colored restorative materials in situ. Journal of dentistry. 2008;36:261-7.

21. Zuryati AG, Qian OQ, Dasmawati M. Effects of home bleaching on surface hardness and surface roughness of an experimental nanocomposite. Journal of conservative dentistry. 2013;16:356.

22. Lıma DANL, De Alexandre RS, Martıns ACM, Aguiar FHB, Ambrosano G, Bovı M, Lovadıno JR. Effect of curing lights and bleaching agents on physical properties of a hybrid composite resin. Journal of Esthetic and Restorative Dentistry. 2008;20:266-73.

23. Malkondu Ö, Yurdagüven H, Say EC, Kazazoglu E, Soyman M. Effect of bleaching on microhardness of esthetic restorative materials. Operative dentistry. 2011;36:177-86.

24. Joiner A. The bleaching of teeth: a review of the literature. Journal of dentistry. 2006;34:412-9.

\section{Conflict of Interest}

The authors have declared that no conflict of interest exist. 